\title{
NGF-OME: ITS METABOTROPHIC EXPRESSION Homage to Rita Levi-Montalcini
}

\author{
George N. Chaldakov ${ }^{1}$, Luigi Aloe ${ }^{2}$, Mariyana G. Hristova ${ }^{1}$, Anton B. Tonchev ${ }^{1}$, Vesselka Nikolova ${ }^{3}$, \\ Plamen Panayotov ${ }^{3}$, and Peter I. Ghenev ${ }^{4}$ \\ ${ }^{1}$ Laboratory of Cell Biology, Medical University, Varna, Bulgaria, ${ }^{2}$ Institute of Neurobiology and \\ Molecular Medicine, National Research Council (CNR), Rome, Italy, ${ }^{3}$ Clinic of Cardiovascular Surgery \\ and ${ }^{4}$ Department of General and Clinical Pathology, Varna, Bulgaria
}

\begin{abstract}
Nowadays, in the postgenome time, many "-ome" studies have emerged including proteome, transcriptome, interactome, metabolome, adipokinome, connectome. In this vein, the catchall term NGF-ome embodies all the actions of NGF in health and disease. Accordingly, the present Festschrift, also tabula gratulatoria, is to honor and acknowledge the contributions of the distinguished neuroscientist and magistra Rita Levi-Montalcini, the Nobel Prize winner-1986 for the discoverer of NGF. Today, $N G F$ and another neurotrophin, brain-derived neuroptrophic factor (BDNF), are well recognized to mediate multiple biological phenomena, ranging from the neurotrophic through immunotrophic and epitheliotrophic to metabotrophic effects. These latter effects are involved in the maintenance of cardiometabolic homeostasis (glucose and lipid metabolism as well as energy balance, and cardioprotection). Circulating and/or tissue levels of NGF and BDNF are altered in cardiometabolic diseases (atherosclerosis, obesity, type 2 diabetes, metabolic syndrome, and type 3 diabetes/Alzheimer's disease). A hypothesis thus emerged that a metabotrophic deficit due to the reduction of NGF/BDNF availability and/or utilization may be implicated in the pathogenesis of cariometabolic and neurodegenerative diseases. The present challenge is therefore to cultivate a metabotrophic thinking about how we can modulate NGF/BDNF secretion and signaling for the benefit of human cardiometabolic and mood health. Biomed Rev 2010; 21: 25-29.
\end{abstract}

Key words: NGF, BDNF, metabotrophins, cardiometabolic diseases

Received 11 December 2010, accepted 23 December 2010

Correspondence: Dr George N. Chaldakov, Laboratory of Cell Biology, Medical University, BG-9002 Varna, Bulgaria. Tel.: +359 52754 394, E-mail: chaldakov@yahoo.com 


\section{INTRODUCTION}

\section{"Ome sweet ome"}

Initial part of the title of article by Lichtman JW and Sanes JR published in

Curr Opin Neurobiol 2008;18:346-353.

Recent studies provide evidence that morbid obesity is a major burden of human health that plays a pivotal role in the development of cardiometabolic diseases (CMD) (Table 1), also non-alcoholic steatohepatitis, obstructive sleep apnea syndrome, polycystic ovary syndrome, and Alzheimer's disease. These are among the major health, social and economic evils of Homo sapiens recens, globally. The World Health Organization has predicted a "globesity epidemic" with more than one billion adults being overweight (BMI over $25 \mathrm{~kg}$ / $\mathrm{m}^{2}$ ) and at least 400 million of these being clinically obese (BMI over $30 \mathrm{~kg} / \mathrm{m}^{2}$ ). Moreover, CMD are associated with cognitive and mood disorders including Alzheimer's disease and depression (1-8). Arguably, we have learned more about the molecular control of food intake and energy homeostasis, particularly, the role played by adipose tissue in the pathogenesis of various diseases, including CMD. Cumulatively, such an adipocentric approach (8-13) has integrated the traditional cardovascular risks (age, sex, smoking, hypertension, dyslipidemia, homocysteinemia) and abdominal obesity and related features of the metabolic syndrome, hence, global cardiometabolic risk (14-16, cf. 17-19).

\section{IMPLICATION OF NGF AND BDNF IN CARDIOMETABOLIC DISEASE: RESULTS OF A DREAM}

During his student life at the Medical University, Varna, Bulgaria, one of us (GNC) used to work four years (1962-1966) as research associated at the Department of Pharmacology. It was that period of time when he for the first time "met" Professor Rita Levi-Montalcini, reading her first papers on nerve growth factor (NGF). Since then he has being infected by this talented molecule, and thought how to reach her Institute in Rome, Italy. Although some colleagues told him that it is very much difficult pursuit, he continued to believe more in the art of dream as presented by Emily Dickinson's To Make a Prairie (To make a prairie it takes a clover and one bee,/ One clover, and a bee,/And revery./ The dream alone will do, / If bees are few.)

Although in 1986-1987 (in Japan) as well as in 1991-1992 (in England) he liked to study the effect of NGF on vascular smooth muscle cells in culture and the expression of NGF in
Table 1. Selected list of cardiometabolic diseases
Atherosclerosis
Hypertension
Acute coronary syndromes
Myocardial infarction
Obesity
Type 2 diabetes mellitus
Metabolic syndrome
Metabolic-cognitive syndrome (2)
Type 3 diabetes mellitus $(1,3-5)^{*}$

* For references for other diseases, see the text.

perivascular mast cells knowing Aloe and Montalcini publication (20), the host scientists have ignored his hypotheses. But not his dream! On its road, he, in 1995 contacted Luigi Aloe and invited him to contribute to Biomedical Reviews. In 1997 he has applied for NATO Research Fellowship, which required acceptance letter by the host institution. Obviously, his dream asked Luigi Aloe about and he provided him with such a letter, consequently awarded a fellowship allowing him appeared in the Institute of Neurobiology, CNR, Rome, in June 1998. During this first four months there as well as almost each year further on, he was honored of meeting in vivo many times Rita Levi-Montalcini.

\section{NGF-OME PROJECT}

At the beginning of this century the Human Genome Project was finalized estimating over 30000 genes encoding more than 100000 functionally distinct proteins. As happened usually, one solved problem delivered many unsolved ones. Thus in the postgenome time, many "-ome" projects have emerged including proteome, transcriptome, interactome, metabolome, adipokinome, connectome. In this vein, all the actions of NGF in health and disease are herein referred to as NGF-ome.

Since 1951 when the NGF was discovered followed by the discovery of other neurotrophins including brain-derived neurotrophic factor (BDNF) (Table 2), it has been increasingly recognized that life at neuronal level requires trophic support (21-26).

As often occurs, the framework of an initial conception of the role of a newly discovered biomolecule extends in the light of emerging findings. This was also the case for NGF. During some 25 years after its discovery, there have been few reasons given to indicate that NGF acts on nonneuronal cells. 
Table 2. Members of the protein family of neurotrophins

\author{
NGF \\ Pro-NGF \\ LIP-1, LIP-2* \\ BDNF \\ Pro-BDNF \\ Neurotrophin (NT-3, NT 4/5, NT-6, NT-7)
}

* Two peptides derived from the pro-NGF: LIP1 is a 29-amino acid peptide, LIP2 is a 38-amino acid peptide, both corresponding to sequences within the NGF (47-49).

Thus, in 1975, Aloe and Levi-Montalcini have made an experiment demonstrating that treatment of newborn rats with NGF caused an increase in the number of mast cells in various organs. These findings (20) have triggered the study on neuroimmune interaction, leading to today's accumulation of evidence that NGF is not only for neuronal life. Indeed, "the submerged areas of the NGF iceberg loom very large", Rita Levi-Montalcini stated in her Nobel prize lecture reviewing 35 years of research on NGF (22).

Cumulatively, studies in the past three decades have revealed that the neurotrophins NGF and BDNF are not only stimulating for nerve growth and survival, but also exert trophic effects over (i) immune cells, acting as immunotrophins (20,27), (ii) keratinocytes, enterocytes, prostate and breast epithelial cells, acting as epitheliotrophins (see 21), (iii) endothelial cells, acting as angiogenic factors (28), and (iv) glucose, lipid and energy homeostasis, pancreatic beta cell and vascular system as well as wound healing, and thus designated metabotrophins (from Greek metabole and trophe, nutrition, means "nutritious for metabolism") $(8,18)$.

\section{METABOTROPHIC NGF AND BDNF}

Noteworthy, (i) pancreatic beta cells secrete NGF and express its receptor, tyrosine-kinase A (TrkA), these findings being implicated in the pathogenesis of diabetes mellitus (29-32), and (ii) systemic and/or local levels of the major metabotrophins, NGF and BDNF, are altered (reduced or, probably, compensatory elevated) in the major CMD (coronary atherosclerosis, obesity, diabetes, metabolic syndrome) (33-42), including acute coronary syndromes (43), and (iii) administration of BDNF improves both energy and glucose homeostasis $(44,45)$. Metabotrophic effects of NGF and BDNF are summarized in Table 3.
Table 3. NGF and BDNF as metabotrophins

NGF shares homology with proinsulin

NGF/BDNF are produced by pancreatic beta cells and exert insulinotropic effect

NGF/BDNF are trophic factors for pancreatic beta cells, also improve beta cell transplantation

NGF up-regulates expression of LDL receptor-related protein

NGF inhibits glucose-induced down-regulation of caveolin-1

NGF improves antioxidant homeostasis

NGF/BDNF decrease food intake

NGF supplementation rescues silent myocardial ischemia in diabetes mellitus

Healthy lifestyle increases brain and/or circulating levels of NGF/BDNF

Atherogenic risk factors (e.g., high fat diet) decrease NGF/BDNF levels

NGF improves diabetic erectile dysfunction

Circulating NGF levels are increased in the early stage of romantic love

* For the implication of NGF in nerve sprouting in sudden cardiac death, see 50,51. References for other items are listed in 8,9.

\section{CONCLUSION}

The discussed findings may implicate the metabotrophic expression of NGF-ome in the pathogenesis of cardiometabolic and neurodegenerative diseases. This hypothesis may open new approaches in the search of exogenous metabotrophic factors, such as (i) small molecules boosting secretory and/ or signaling pathways of both NGF and BDNF $(8,18,19)$, (ii) incretin mimetics and receptor agonists, because the insulinotropic hormone glucagon-like peptide-1 (GLP-1) and exendin-4, a GLP-1 receptor agonist, exert both neurotrophic and metabotrophic effects (46), and (iii) agents interfering with vascular endothelium growth factor (28).

The present challenge is therefore to learn more about the metabotrophic potential of human NGF-ome in the pathogenesis and therapy of cardiometabolic and neurodegenerative diseases. 


\section{REFERENCES}

1. Sridhar GR, Thota H, Allam AR, Babu CS, Prasad AS, Divakar C. Alzheimer's disease and type 2 diabetes mellitus: the cholinesterase connection? Lipids Health Dis 2006; 5: 28-31.

2. Frisardi V, Solfrizzi V, Seripa D, Capurso C, Santamato A, Sancarlo D, et al. Metabolic-cognitive syndrome: a cross-talk between metabolic syndrome and Alzheimer's disease. Ageing Res Rev 2010; 9: 399-417.

3. Lester-Coll N, Rivera EJ, Soscia SJ, Doiron K, Wands JR, de la Monte SM. Intracerebral streptozotocin model of type 3 diabetes: relevance to sporadic Alzheimer's disease. J Alzheimer's Dis 2006; 9:13-33.

4. Manning S. Diabetes and dementia: a common link of coincidental coexistence. Biomed Rev 2007; 18: 59-64.

5. Milionis HJ, Florentin M, Giannopoulos S. Metabolic syndrome and Alzheimer's disease: A link to a vascular hypothesis? CNC Spectr 2008; 13: 606-613.

6. Molteni R, Barnard RJ, Ying Z, Roberts CK, Gómez-Pinilla F. A high-fat, refined sugar diet reduces hippocampal brain-derived neurotrophic factor, neuronal plasticity, and learning. Neuroscience 2002; 112: 803-814.

7. de la Monte S, Wands JR. Alzheimer's disease is type 3 diabetes - evidence reviewed. J Diabetes Sci Technol 2008; 2: 1101-1113.

8. Chaldakov GN, Tonchev AB, Aloe L.NGF and BDNF: from nerves to adipose tissue, from neurokines to metabokines. Relevance to neuropsychiatric and cardiometabolic diseases. Riv Psichiatr 2009; 44: 79-87.

9. Chaldakov, G.N., Fiore, M., Ghenev, P.I., Stankulov, I.S., Aloe, L. Atherosclerotic lesions: possible interactive involvement of intima, adventition and associated adipose tissue. Int Med $J$ 2000; 7: 43-49.

10. Chaldakov GN, Stankulov IS, Fiore M, Ghenev PI, Aloe L. Nerve growth factor levels and mast cell distribution in human coronary atherosclerosis. Atherosclerosis 2001; 159:57-66.

11. Trayhurn P, de Heredia FP, Wang B, de Oliveira C, González-Muniesa P, Wood, I.S. Cellular hypoxia: a key modulator of adipocyte function in obesity? Adipobiology 2009; 1: 19-26.

12. Chaldakov GN, Stankulov IS, Hristova M, Ghenev PI. Adipobiology of disease: adipokines and adipokine-targeted pharmacology. Curr Pharm Des 2003; 9: 1023-1031.

13. Catalán V, Rodríguez A, Becerril S, Sáinz N, Gómez-Ambrosi J, Frühbeck G. Adipopharmacology of inflammation and insulin resistance. Biomed Rev 2006; 17: 43-51

14. Després JP, Arsenault BJ, Côte M, Cartier A, Lemieux I.
Abdominal obesity: the cholesterol of the 21 st century? Can J Cardiol 2008; 24 (Suppl D): 7D-12D.

15. Palmieri L, Panico S, Vanuzzo D, Ferrario M, Pilotto L, Sega R, Cesana G, Giampaoli S; Gruppo di Ricerca del Progetto CUORE. Evaluation of the global cardiovascular absolute risk: the Progetto CUORE individual score. Ann Ist Super Sanita 2004; 40:393-399.

16. Shimabukuro M. Cardiac adiposity and global cardiometabolic risk: new concept and clinical implication. Circ J 2009; 73:27-34.

17. Duhne M, Myrian V, Larque C, Gutiérrez, Robles G, Hiriart M. Nerve growth factor, pancreatic beta cells, adipose tissue and diabetes mellitus. Adipobiology 2009; 1: $117 \mathrm{~A}$

18. Chaldakov GN, Fiore M, Tonchev AB, Dimitrov D, Pancheva R, Rančič G, Aloe L. Homo obesus: a metabotrophin-deficient species. Pharmacology and nutrition insight. Curr Pharma Des 2007; 13, 2176-2179.

19. Chaldakov GN, Tonchev AB, Fiore F, Hristova MG, Pancheva R, Rancic G, Aloe L. Implications for the future of obesity management. In: Frühbeck G, editor. Peptides in Energy Balance and Obesity. CAB International. 2009, pp 370-389.

20. Aloe L, Levi-Montalcini R. Mast cells increase in tissues of neonatal rats injected with the nerve growth factor. Brain Res 1997; 133: 358-366.

21. Aloe L, Calzà L, editors. NGF and Related Molecules in Healthy and Disease (vol 146, Prog Brain Res). Elsevier, 2004.

22. Levi-Montalcini R. The nerve growth factors 35 years later. Science 1987; 237: 1154-1162.

23. Levi-Montalcini R, Skaper SD, Dal Toso R, Petrelli L, Leon A. Nerve growth factor: from neurotrophin to neurokine. Trend Neurosci 1996; 19: 514-520.

24. Levi-Montalcini R. The nerve growth factor and the neuroscience chess board. Arch Ital Biol 2003; 141: 85-88.

25. Aloe L, Tirassa P, Bracci-Laudiero L. Nerve growth factor in neurological and non-neurological diseases: basic findings and emerging pharmacological prospectives. Curr Pharm Des 2001; 7: 113-123.

26. Fiore M, Chaldakov GN, Aloe L. Nerve growth factor as a signaling molecule for nerve cells and also for the neuroendocrine-immune systems. Rev Neurosci 20:133145, 2009.

27. Fainzilber M, Carter BD. From neurotrophins to immunotrophins. EMBO Reports 2002; 3: 1029-1034.

28. Lazarovici P, Marcinkiewicz C, Lelkes PI. Cross talk between the cardiovascular and nervous systems: neu- 
rotrophic effects of vascular endothelial growth factor (VEGF) and angiogenic effects of nerve growth factor (NGF)-implications in drug development. Curr Pharm Des 2006; 12: 2609-2622.

29. Cabrera-Vásquez S, Navarro-Tableros V, Sánchez-Soto C, Gutiérrez-Ospina G, Hiriart M. Remodelling sympathetic innervation in rat pancreatic islets ontogeny. 2009; BMC Dev Biol 9: 34-44.

30. Rosenbaum T, Vidaltamayo R, Sánchez-Soto MC, Zentella A, Hiriart M. Pancreatic beta cells synthesize and secrete nerve growth factor. Proc Natl Acad Sci USA 95: 7784-7788, 1998.

31. Larrieta ME, Vital P, Mendoza-Rodriguez A, Cerbón M, Hiriart M. Nerve growth factor increases in pancreatic beta cells after streptozotocin-induced damage in rats. Exp Biol Med (Maywood) 2006; 231: 396-402.

32. Hiriart-Urdanivia M, Tableros VN, Velasco M, Larqué C, Cabrera-Vásquez S, Soto CS, et al. Insulin regulation in development and obesity. In: Hiriart-Urdanivia M, Mas-Oliva J, editors. Advances in obesity-diabetes research at UNAM (Universidad Nacional Autónoma de México). Manual Moderno, Mexico, Columbia. 2010; pp 69-79.

33. Abe T, Morgan DA, Gutterman DD. Protective role of nerve growth factor against postischemic dysfunction of sympathetic coronary innervation. Circulation 1997; 95: 213-220.

34. Hasan W, Jama A, Donohue T, Wernli G, Onyszchuk G, Al-Hafez B, Bilgen M, Smith PG. Sympathetic hyperinnervation and inflammatory cell NGF synthesis following myocardial infarction in rats. Brain Res 2006; 1124: 142-154.

35. Bulló M, Peeraully MR, Trayhurn P, Folch J, Salas-Salvadó J. Circulating nerve growth factor levels in relation to obesity and the metabolic syndrome in women. Eur $J$ Endocrinol 2007; 157: 303-310.

36. Cheng JT, Tong YC. Alterations of nerve-growth factor and $\mathrm{p} 75(\mathrm{NTR})$ expressions in urinary bladder of fructose-fed obese rats. Neurosci Lett 2008; 441:25-28.

37. Kangavari S, Oh YS, Zhou S, Youn HJ, Lee MY, Jung WS, et al. Radiofrequency catheter ablation and nerve growth factor concentration in humans. Heart Rhythm 2006; 3: 1150-1155.

38. Sornelli F, Fiore M, Chaldakov GN, Aloe L. Adipose tissue-derived nerve growth factor and brain-derived neurotrophic factor: results from experimental stress and diabetes. Gen Physiol Biophys 2009; 28:179-83.

39. Sposato V, Manni L, Chaldakov GN, Aloe L. Streptozotocin-induced diabetes is associated with changes in
NGF levels in pancreas and brain. Arch Ital Biol 2007; 145: 87-97.

40. Geroldi D, Minoretti P, Emanuele E. Brain-derived neurotrophic factor and the metabolic syndrome: More than just hypothesis. Med Hypotheses 2006; 67: 195-196.

41. Golden E, Emiliano A, Maudsley S, Windham BG, Carlson OD, Egan JM, et al. Circulating brain-derived neurotrophic factor and indices of metabolic and cardiovascular health: data from the Baltimore Longitudinal Study of Aging. PLoS One. 2010;5: e10099.

42. Chaldakov GN, Fiore M, Tonchev AB, Aloe L. Neuroadipology: a novel component of neuroendocrinology. Cell Biol Int 2010; 34:1051-1053

43. Manni L, Nikolova V, Vyagova D, Chaldakov GN, Aloe L. Reduced plasma levels of NGF and BDNF in patients with acute coronary syndromes. Int $J$ Cardiol 2005; 102:169-171.

44. Wang C, Godar RJ, Billington CJ, Kotz CM. Chronic administration of brain-derived neurotrophic factor in the hypothalamic paraventricular nucleus reverses obesity induced by high-fat diet. Am J Physiol Regul Integr Comp Physiol 2010; 298:R1320-1332.

45. Yamanaka M, Itakura Y, Ono-Kishino M, Tsuchida A, Nakagawa $T$, Taiji $M$. Intermittent administration of brain-derived neurotrophic factor (BDNF) ameliorates glucose metabolism and prevents pancreatic exhaustion in diabetic mice. J Biosci Bioengen 2008; 105: 395-402.

46. Perry T, Lahiri DK, Chen D, Zhou J, Shaw KT, Egan JM, Greig NH. A novel neurotrophic property of glucagonlike peptide 1: a promoter of nerve growth factor-mediated differentiation in PC12 cells. J Phramacol Exp Ther 2002; 300:958-966.

47. Clos J, Dicou E. Two peptides derived from the nerve growth factor precursor enhance cholinergic enzyme activities in vivo. Brain Res Dev Brain Res 1997; 99:267270.

48. Dicou E. Multiple biological activities for two peptides derived from the nerve growth factor precursor. Biochem Biophys Res Commun 2006; 347: 833-837.

49 Dicou E. High levels of the proNGF peptides LIP1 and LIP2 in the serum and synovial fluid of rheumatoid arthritis patients: evidence for two new cytokines. $\mathrm{J} \mathrm{Neu}$ roimmunol 2008; 194: 143-146.

50. Zhou S, Chen LS, Miyauchi Y, Miyauchi M, Kar S, Kangavari $\mathrm{S}$, et al. Mechanisms of cardiac nerve sprouting after myocardial infarction in dogs. Circ Res 2004; 95: 76-83.

51. Ieda M, Fukuda K. Cardiac innervation and sudden cardiac death. Curr Cardiol Rev 2009; 5: 289-295. 